\title{
片脚立位姿勢におけるライトタッチの効果 \\ 一ロコモーショントレーニングの基礎的検討一一

\author{
Effect of Light Fingertip Contact in the One-leg Standing Position: \\ Basic Study of Locomotion Training
}

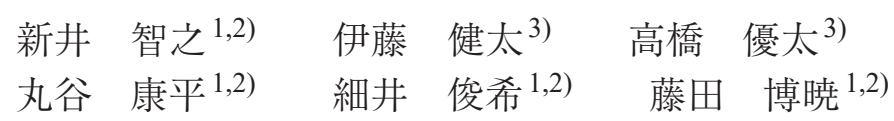

TOMOYUKi ARAI, RPT, $\mathrm{PhD}^{1,2)}$, Kenta ITO, RPT ${ }^{3)}$, YUUtA TAKAHASHI, RPT ${ }^{3)}$, KoHei MARUYA, RPT, PhD ${ }^{1,2)}$, TOSHIKI HOSOI, RPT, $\mathrm{PhD}^{1,2)}$, HIROAKI FUJTTA, RPT, $\mathrm{PhD}^{1,2)}$

1) Department of Physical Therapy, Faculty of Health and Medical Care, Saitama Medical University: 981 Kawakado, Moroyama, Iruma-gun, Saitama 350-0496, Japan TEL+81 49-295-1001 E-mail: araitm124@gmail.com

2) Orthopaedic Institute for the Elderly

3) Department of Rehabilitation, Maruki Memorial Medical and Social Welfare Center

Rigakuryoho Kagaku 34(5): 559-564, 2019. Submitted Mar. 8, 2019. Accepted Apr. 22, 2019.

ABSTRACT: [Purpose] This study aimed to examine the influence of light fingertip contact in a one-leg standing position on an unstable surface on the postural sway and electromyographic (EMG) activity in the lower extremity muscles. [Participants and Methods] Thirteen healthy male volunteers participated in this study. Participants stood on one leg on an unstable surface, and their postural sway and EMG activity were measured. Experimental trials included the following three contact conditions: (1) one-leg standing without touching, NT; (2) one-leg standing with the right fingertip lightly touching $(<1 \mathrm{~N})$, LT; (3) one-leg standing with the right fingertip forcefully touching $(>5$ N), FT. [Results] The postural sway of the LT condition was significantly lower than that of the NT condition. The EMG activity in the lower extremity muscles showed no difference between the NT and LT conditions. [Conclusion] These results indicate that light fingertip contact while standing on an unstable surface decreased postural sway and maintained EMG activity in the lower extremity muscles.

Key words: one-leg-standing, light fingertip contact, locomotion training

要旨：〔目的〕本研究は不安定面上での片脚立位時のライトタッチの効果を, 足圧中心動摇と下肢筋の筋活動から検 討することを目的とした。 [対象と方法] 対象は健常男子大学生 13 名とした。支持なし（フリー），ライトタッチ（1 $\mathrm{N}$ 以下の接触), フォースタッチ（5 N 以上の接触）の 3 条件で, 足圧中心動摇と 6 つの筋の筋電図を測定した。〔結 果]総軌跡長, 矩形面積, 実効值面積は, フリー条件に比ベ, ライトタッチとフォースタッチが有意に低值を示した. またライトタッチ条件に比べ，フォースタッチが有意に低值を示した．大殿筋，大腿二頭筋，前脛骨筋，非腓腹筋の 筋活動においては，フリーとライトタッチ時の％RMS に有意差はなかった。〔結論〕片脚立位中のライトタッチは, 下肢筋の筋活動を減少させずに，足圧中心動摇を減少させる効果があることが示された，

キ一ワード: 片脚立位, ライトタッチ, ロコモーショントレーニング

1) 埼玉医科大学 保健医療学部 理学療法学科 : 埼玉県入間郡毛吕山町川角 981 (₹ 350-0496) TEL 049-295-1001

2) 高齢者運動器疾患研究所

3) 丸木記念福祉メディカルセンター リハビリテーション科

受付日 2019 年 3 月 8 日 受理日 2019 年 4 月 22 日 


\section{I. はじめに}

超高齢社会を迎えた我が国においては，高齢人口の増 加に伴い, 要介護認定を受ける高齢者が増加している1). 要支援・要介護認定を受ける主な原因のなかで, 関節疾 患や転倒 ・骨折といった運動器疾患は約 2 割を占めてお り 2), 運動器の健康を保つための取り組みが求められて いる.

このような現状を受け, 日本整形外科学会は運動器の 障害によって移動機能が低下した状態を「ロコモテイブ シンドローム：運動器症候群（以下，ロコモ)」と定義 ( ${ }^{3)}$, 運動器の健康を保つための取り組みを進めている。 ロコモを判断するための方法は, セルフチェックの方法 としてのロコチェック ${ }^{4)}$, 臨床的な判断方法としての 3 つのロコモ度テスト5)が紹介されており，それぞれ高 齢者の運動機能や生活機能低下との関連が報告されてい る.

一方，ロコモを予防する方法は，ロコモーショント レーニング (以下，ロコトレ）が紹介されている6)。ロ コトレの主要な運動は, 開眼片脚立位（ダイナミックフ ラミンゴ）とスクワットであり，どちらも特別な機器を 使用せず自宅で行うことができる運動となっている。

ロコモーショントレーニングの一つである開眼片脚立 ちトレーニングは, 高齢者のバランス能力を向上させる トレーニングとして有用であり，一般的に処方されてい る。さらに松本ら 7)によれば，片脚立ち時の下肢筋の\% MVC は，約 40〜 $80 \%$ と高值を示し，若年者よりも高 い\% MVCを示したことから，片脚立ちトレーニングは, バランスのみならず, 筋力増強訓練としても適切な負荷 量の運動であると報告されている。そのため, 片脚立ち トレーニングは, バランスと筋力を向上させるために有 用なトレーニングであると考えられる.

しかし，高齢者が自宅で片脚立ちトレーニングを実施 する場合，転倒に注意しなければいけない，特にバラン 又能力が低く転倒の恐れがある高齢者の場合は, 何か支 持物につかまりながら行うことが推奨されている6)。支 持物に掴まることで，姿勢が安定しバランスを崩すこと が少なくなるが，一方では，上肢による支持で身体を支 えるため, 片脚立位中の下肢の筋活動は低下してしまう という久点も存在する。

立位姿勢の保持には, 視覚系, 前庭系, 体性感覚系な どの感覚系や筋, 関節, 骨などの筋骨格系, 環境条件な ど様々なものが関与しているといわれている ${ }^{8)}$. 近年で は，体性感覚によるバランス能力への影響を調査した報 告として，力学的に支持にならない（1 N 以下）ほど軽 く触れること（以下，ライトタッチ）により, 片脚立位 中の姿勢動摇が減少することが明らかとなった ${ }^{9)}$. ライ トタッチは力学的支持ではなく10), 体性感覚情報を付 加している11,12). 安定面上でライトタッチを行った研
究では，健常成人であっても 9,11)，高齢者であっても 13) ライトタッチによって足圧中心動摇は減少したと報告さ れている. ライトタッチが力学的支持ではないとすれば, 片脚立位トレーニング中にライトタッチを用いることで, 下肢の筋活動の減少を少なくし, 姿勢の動摇が減少する ことができると推察される。 ライトタッチの効果が明ら かとなれば, バランス能力が低下している高齢者が, 自 宅で安全にロコトレを実施する場合の運動方法として有 用となる可能性がある.

開眼両脚立位中の下肢の筋活動を測定した研究では, ライトタッチを用いても, 支持なしの条件や力学的に支 持した条件と比較しても，筋活動は変わらないと報告さ れている 14,15)。一方で, タンデム立位の姿勢で行った 研究では, ライトタッチにより, 下肢筋の活動パターン が変化したという報告もある 16). 以上のことから，開 眼両脚立位より，難易度の高い立位姿勢であれば，ライ トタッチにより下肢の筋活動が変化する可能性が推察さ れるが, 片脚立位姿勢において, 下肢の筋活動を測定し た研究は少ないのが現状である。

Iwamotoら 17) は，片脚立位姿勢におけるライトタッ チの効果として, 足圧中心動摇の減少と足関節周囲筋の 共同収縮の減少がみられたと報告している。また Uchida ら 18) は, ライトタッチ条件では, 力学的支持が ある条件に比べて片脚立位持の腓腹筋, 前脛骨筋の筋活 動が高いことを報告している。しかし，これまでの研究 では，股関節周囲筋も含めて，片脚立位時のライトタッ チの効果を示した報告はない.

本研究の測定肢位は, 床にクッション性のあるフォー ムラバーを引き, 不安定な床面上での片脚立位姿勢とし た。本研究では, 対象が健常男子大学生となるため, 不 安定な床面にすることで課題の難易度を上げ，足底から の体性感覚情報を減弱する条件を設定することで，模擬 的に姿勢保持能力が低下したような状態を作り，高齢者 の片脚立ちトレーニングを想定し研究を行うこととし た. よって本研究の目的は, ロコトレである片脚立位卜 レーニングの基礎的検討として，片脚立位姿勢における ライトタッチの効果を足圧中心動摇と下肢筋の筋活動か ら検討することとした。

\section{II. 対象と方法}

\section{1. 対象}

対象は, 健常男子大学生 13 名 (年齢 $22.4 \pm 0.9$ 歳, 身長 $172.8 \pm 4.2 \mathrm{~cm}$, 体重 $71.4 \pm 10.9 \mathrm{~kg}$ 〔平均 \pm 標 準偏差〕）とした。除外基準は下肢に整形疾患を有する 者とした。対象者全員には, 本研究の趣旨と個人情報の 守秘義務について説明し, 口頭かつ紙面にて同意を得 た。 また本研究は埼玉医科大学保健医療学部倫理委員会 の承認（承認番号：85）を受けて実施した. 
2. 方法

片脚立位の測定は, 重心動摇計の上にクッション性が あるフォームラバーを敷き, 不安定な床面とし, その上 で右下肢にて片脚立位を支持なし（以下，フリー）， ラ イトタッチ, フォースタッチの 3 条件をランダム化して 3 回ずつ行った。 1 施行 30 秒間行い, 施行中は前方を 見つめ上肢は体側に垂らし, 挙上肢は股間節 $0^{\circ}$, 膝関 節 90の肢位とした 17,18)（図 1).

対象者はライトタッチ・フォースタッチの 2 条件の際 に右手示指を対象者の足尖部から外側 $15 \mathrm{~cm}$, 前方 15 $\mathrm{cm}$ の位置に設置し, 高さを対象者の肘関節が $30^{\circ}$ 屈曲 位となる位置に設定したピンチメーター（PH-7010 Feedback Logger，ディケイエイチ社製）の上に置いた. そのとき右手示指以外の指が台に接触しないように注意 を呼びかけた。

ライトタッチは右手示指の $1 \mathrm{~N}$ 以下の接触とし, フォースタッチは右手示指の $5 \mathrm{~N}$ 以上の接触とした ${ }^{5)}$. 指先にかかる力はピンチメーターを使用して測定し, ラ

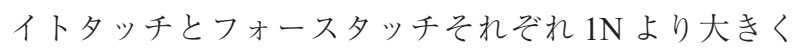
なった場合, $5 \mathrm{~N}$ 未満となった場合には, 音が鳴り接触 力を確認した。施行途中に音がなってしまった際は失敗 とし, 施行をやり直した。

足圧中心動摇の測定には, 重心動摇計（TWINGRAVICORDER GP-6000，アニマ社製）を使用した。 計測は重心動摇計のプレート 1 枚で行い, 年齢・身長 · 体重を入力後, 検査条件を開眼, 時間を 30 秒, 周期を $100 \mathrm{~Hz}$ に設定し，プレートの上に重心動摇計付属のラ バーを設置した。測定したデータの解析は, 先行研究 ${ }^{19)}$

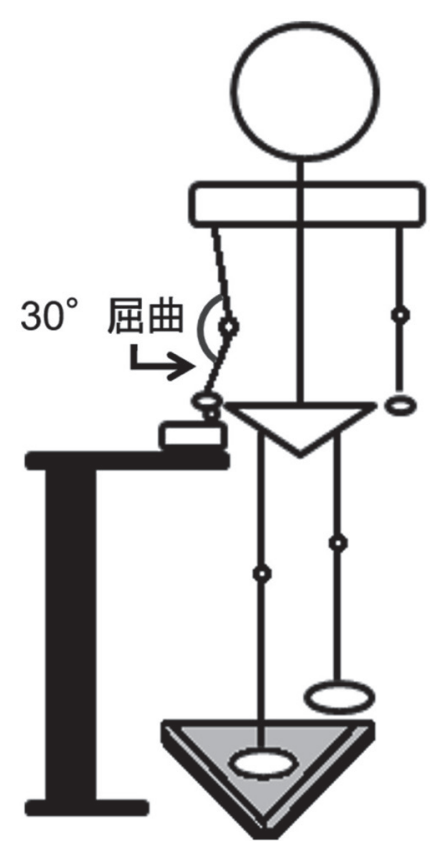

図1 測定肢位
をもとに, 総軌跡長, 矩形面積, 実効值面積とした。総 軌跡長は，足圧中心の移動距離であり，身体動摇の不安 定さを示すものであり, 動摇が少ない場合は距離が小さ くなる值である，矩形面積は，足圧中心の軌跡の占める 範囲の X 軸成分と $\mathrm{Y}$ 軸成分の最大值から, 両者の積に よって得られる面積であり, 対象者の動摇した範囲を示 すものである。平衡障害の把握や治療効果の評価に役立 つ外周面積との相関が高いことが報告されている 19) 項 目であるが，偶発的な動摇も考慮される值である。実効 值面積は, 実効值の Root Mean Square（以下, RMS) を算出して得られる面積である。実効值面積は, 動摇の 密度も考慮されている点で優れているとされており20), 偶発的な動摇に影響されにくい項目であると考えられる。

足圧中心の前後左右への最大幅を囲んだ長方形の面積 である矩形面積, 実効值 (平均重心点からのばらつき) を半径とする円の面積である実効值面積を算出した。

下肢筋の活動については, 表面筋電計 (TELEMYO02400, NORAXON 社製) を使用して, 大 殿筋, 中殿筋, 大腿四頭筋, 大腿二頭筋, 前脛骨筋, 腓 腹筋の計 6 筋において, 片脚立位中の表面筋電図を測定 した，各筋の電極添付位置を図 2 に示す。測定した筋電 罒はサンプリング周波数 $1000 \mathrm{~Hz}$ でパソコンに取り込 み, 生波形を全波整流し, その後スムージングでスムー ジングウィンドウ $100 \mathrm{~m} / \mathrm{s}$ で, 1 施行中で姿勢が安定し た 10 秒間の RMS 值を算出した。

また筋活動量を正規化するために, 定量負荷課題とし て Daniels らの徒手筋力検査法 (Manual Muscle Testing : MMT） 5 の大殿筋，中殿筋，大腿四頭筋，大 腿二頭筋, 前脛骨筋の測定方法にて, 最大等尺性収縮に おける筋電図波形を計測し, RMS 值を算出した。なお 腓腹筋においては，長座位にて対象者の踵を持ち験者の 前腕で前足部に徒手抵抗をかけ，最大等尺性収縮を行い 筋電図波形を計測した。最大等尺性収縮時の RMS 值で 片脚立位時の RMS 值を除した\% RMS を算出し，解析 に用いた。

統計処理は片脚立位時の 3 条件時の足圧中心動摇（総 軌跡長, 矩形面積, 実効值面積) と6つの筋それぞれの 3 条件での\% RMS について, Friedman 検定を用い, 有 意水準は $5 \%$ として解析を行った. Friedman 検定の結果, 有意差のみられた項目に関しては, 多重比較として2 群 間ごとの比較を, Wilcoxonの符号順位検定により行っ た。 なお Wilcoxonの符号順位検定では, Bonferroniの 調整有意水準を用い, 0.016 を有意水準とした。統計解 析には IBM SPSS statistics 24.0 を用いた。

\section{III. 結 果}

3 条件における総軌跡長, 矩形面積, 実効值面積の比 較結果を表 1 に表す. Friedman 検定および多重比較の 


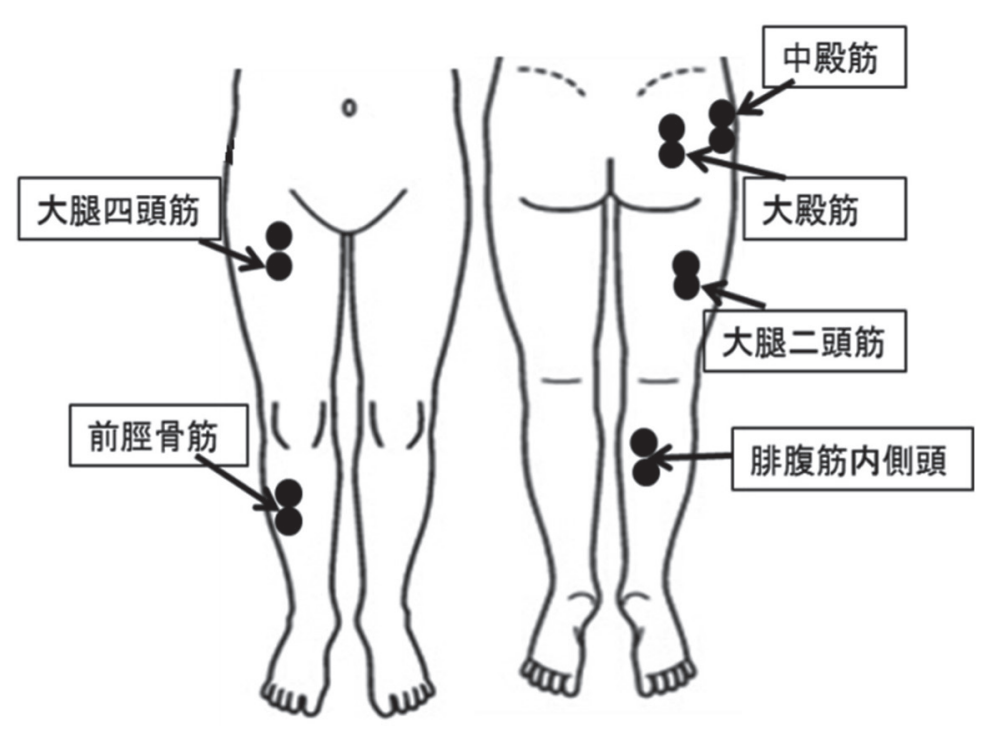

図2 筋電図の電極添付位置

表 13 条件での足圧中心動摇の比較

\begin{tabular}{|c|c|c|c|c|c|}
\hline & (1)フリー & (2)ライトタッチ & (3)フォースタッチ & 有意確率\# & 多重比較 ${ }^{\dagger}$ \\
\hline 総軌跡長（cm） & $153.1 \pm 46.5$ & $119.3 \pm 38.6$ & $81.0 \pm 29.8$ & $<0.01$ & $\begin{array}{l}\text { (1) }>\text { (2) } \\
\text { (1) }>\text { (3) } \\
\text { (2) }>\text { (3) }\end{array}$ \\
\hline 矩形面積 $\left(\mathrm{cm}^{2}\right)$ & $16.5 \pm 7.5$ & $10.0 \pm 4.3$ & $7.7 \pm 4.5$ & $<0.01$ & $\begin{array}{l}\text { (1) }>\text { (2) } \\
\text { (1) }>\text { (3) } \\
\text { (2) }>\text { (3) }\end{array}$ \\
\hline 実効値面積（cm²） & $6.4 \pm 4.2$ & $3.8 \pm 2.9$ & $2.4 \pm 1.8$ & $<0.01$ & $\begin{array}{l}\text { (1) }>\text { (2) } \\
\text { (1) }>\text { (3) } \\
\text { (2) }>\text { (3) }\end{array}$ \\
\hline
\end{tabular}

平均值 \pm 標準偏差. \#: Freedman 検定で検定, †: Wilcoxonの符号付き順位検定で検定, Bonferroni 補正により $\mathrm{p}<0.016$ が有意差あり.

結果, 総軌跡長, 矩形面積, 実効值面積ともに有意差が みられた。その後の多重比較の結果, すべての項目でフ リー条件に比ベ，ライトタッチとフォースタッチが有意 に低值を示した。またすべての項目に扔いて，ライト タッチ条件に比ベ，フォースタッチが有意に低值を示し た。

次に, 3 条件における 6 筋の結果を表 2 に示す。一元 配置分散分析の結果，6筋すべての％RMS に有意差が みられた $(\mathrm{p}<0.05)$. 多重比較の結果, 大殿筋, 中殿筋, 大腿二頭筋，前脛骨筋，非腓腹筋の％RMSに抒いて, フォースタッチ条件に比較して, フリーとライトタッチ では，下肢筋の筋活動が有意に高值を示した。な打中殿 筋のみ, フリーと比較してライトタッチ時の\% RMS が 有意に低值を示したが，その他の筋に执いては，フリー とライトタッチ時の\% RMS に有意差はなかった。

\section{IV. 考 察}

立位での姿勢制御には視覚系, 前庭系, 体性感覚系が, 身体の位置と運動を検知するために働いている。 なかで も体性感覚と姿勢制御との関連を調査した報告では, 指 先でライトタッチにより, 足圧中心動摇の振幅・軌跡長 が減少することが明らかになっている 9,12,13)。また前庭 に障害がある方を対象とした研究においても，足圧中心 動摇が減少し 21,22), 体性感覚系は姿勢制御を行う際に 重要な役割を担っていると考えられる。

本研究では, フォームラバーを敷いた実験を行ってい る。床面を不安定にしていることで，足底からの体制感 覚情報を利用して身体の傾きを把握することが困難にな り, フリーの条件下に打いては, 視覚や前庭覚への依存 度が高くなっていると推察される。 そのような状況下で ライトタッチを付加することは, 指先からの体性感覚情 
表 23 条件での下肢筋活動の比較

\begin{tabular}{|c|c|c|c|c|c|}
\hline & (1)フリー & (2)ライトタッチ & (3)フォースタッチ & 有意確率\# & 多重比較 ${ }^{\dagger}$ \\
\hline 大殿筋（\% ) & $8.3 \pm 6.6$ & $6.9 \pm 6.0$ & $5.3 \pm 4.2$ & $<0.01$ & $\begin{array}{l}\text { (1) }>\text { (3) } \\
\text { (2) }>\text { (3) }\end{array}$ \\
\hline 中殿筋（\%） & $27.3 \pm 17.6$ & $22.9 \pm 14.1$ & $19.0 \pm 13.5$ & $<0.01$ & $\begin{array}{l}\text { (1) }>\text { (2) } \\
\text { (1) }>\text { (3) } \\
\text { (2) }>\text { (3) }\end{array}$ \\
\hline 大腿四頭筋（％） & $5.5 \pm 4.3$ & $4.7 \pm 4.2$ & $4.2 \pm 4.8$ & $<0.05$ & n.s \\
\hline 大腿二頭筋（\%） & $14.3 \pm 11.5$ & $11.8 \pm 12.1$ & $7.6 \pm 6.2$ & $<0.01$ & $\begin{array}{l}\text { (1) }>\text { (3) } \\
\text { (2) }>\text { (3) } \\
\end{array}$ \\
\hline 前脛骨筋（\%） & $36.6 \pm 20.0$ & $37.5 \pm 20.3$ & $20.4 \pm 14.1$ & $<0.01$ & $\begin{array}{l}\text { (1) }>\text { (3) } \\
\text { (2) }>\text { (3) }\end{array}$ \\
\hline 腓腹筋（\%） & $63.5 \pm 39.2$ & $56.1 \pm 31.2$ & $40.3 \pm 19.9$ & $<0.01$ & $\begin{array}{l}\text { (1) }>\text { (3) } \\
\text { (2) }>\text { (3) }\end{array}$ \\
\hline
\end{tabular}

平均值 \pm 標準偏差. \#: Freedman 検定で検定, †: Wilcoxonの符号付き順位和検定で検定, Bonferroni 補正により $\mathrm{p}<0.016$ が有意差あり

報が，減弱した足底からの感覚情報を補完するような役 割をなしていると考えられる。神崎らは，ライトタッチ を付加することで，より身体軸の傾きを正確にとらえ， 足関節周囲のトルクを制御することで，安定した立位を 実現することにつながっていると報告している ${ }^{23)}$ ，以 上の理由により, 本研究においてもライトタッチ条件で は，フリーと比較して，足圧中心動摇が減少したと考え られた。

次に下肢筋の筋活動の結果について述べる。本研究の 結果, 大殿筋, 中殿筋, 大腿二頭筋, 前脛骨筋, 腓腹筋 内側頭において, フォースタッチ条件が, フリーとライ トタッチ条件に比べて, 有意に筋活動が低下していた。 フォースタッチについては, 力学的支持となっているた め, 他の 2 条件に比べて, 筋活動が減少したと考えられ た。一方，ライトタッチ条件における大殿筋，大腿二頭 筋，前脛骨筋，腓腹筋の筋活動は，フリー条件との間に 統計的な有意差はなかった。 以上のことから，ライト 夕ッチは，少なくとも足関節周囲筋や大腿後面の筋にお いては, フリー条件と同程度の筋活動を発揮しているこ とが示された。

先行研究では, ライトタッチ中の下肢筋の筋活動は, フリーやフォースタッチ条件と比較して有意差がなかっ たとしている報告もある14,15)。しかし，これらの先行 研究における測定課題は, 開眼閉脚立位や $30 \mathrm{~cm}$ 台か らの降段動作であり，健常成人を対象にした研究として は課題が容易であった可能性が考えられた。本研究では, 不安定面上での片脚立位を課題としており, 床面が不安 定となり課題の難易度が高かったため, 先行研究とは異 なり，筋活動に有意差がみられたと考えられた。

本研究は, 健常成人を対象にしているが, 不安定面上
での実験であり，模擬的に対象者のバランス機能が低下 している状態を作っており, 高齢者の片脚立位トレーン ングを想定した研究であると考える。本研究の結果, ラ イトタッチ条件下での片脚立位は，下肢筋の筋活動を減 少させずに足圧中心動摇を減少させる効果があることが 示された。高齢者がロコトレを自宅で安全に行う場合, 転倒リスクの少ないトレーニング方法が必要であると考 えられる。 ライトタッチ条件下での片脚立位トレーニン グは，バランス能力や下肢筋力などの身体機能が低下し ている高齢者において, 安全で有用なトレーニング手段 となる可能性が考えられた。

本研究にはいくつかの限界が含まれる。まず対象人数 13 人と少なく, さらに若年男性に限られることが限界 である。そのため年齢や性別が異なる集団においては, 違った結果となる可能性を含んでいる。 今後は対象者数 を増やし, 高齢者や女性などを含めて研究を進めていく 必要があると考える。次に測定機器の都合により, フォースタッチの条件が $5 \mathrm{~N}$ 以上であり，支持する力の 上限を設定できなかった点が挙げられる。 そのため フォースタッチ条件では測定ごとに, 支持する力を一定 にできていないことは, 結果に影響する可能性があると 考えられる。

本研究では, 若年男性を対象とし, 不安定面上にて片 脚立位におけるライトタッチの効果を検討することを目 的としている。結果としてライトタッチを行うことで, フリー条件に比べて足圧中心動摇は減少し, フリー条件 と同程度に，下肢筋の筋活動を保つことが可能であっ た．高齢者がバランストレーニングを行う場合，運動時 の転倒に注意する必要があるため, 支持物につかまるこ とを指導することが多いと考えられる。ライトタッチは, 
片脚立位時の身体動摇を減らし，かつ筋活動を減少させ ない方法であるため, 運動中にバランスを崩す可能性の ある高齢者に対する有用なトレーニング方法として活用 できる可能性がある.

利益相反 本論文に関して筆頭著者および共著者に開示 すべき利益相反はない.

謝辞 本研究を実施するうえで，調査にご協力いただい た埼玉県伊奈町の関係各位，および特定非営利活動法人 高齢者運動器疾患研究所のスタッフの皆様に深謝致しま す。また本研究はJSPS 科研費 (JP25870680, JP18K02225), および平成 26 年度長寿科学研究者支援 事業助成金（研究代表者：新井智之）の助成の一部によ り行われた研究です。記して謝意を表します。

\section{引用文献}

1) 内閣府：平生 29 年版高齢社会白書（全体版）第 1 章 高齢者 の状況 第2節 高齢者の姿と取り巻く環境の現状と動向. http://www8.cao.go.jp/kourei/ whitepaper/w-2017/html/zenbun/s1 $23 . h t m l$ (閲覧日2019年2月25日）。

2) 厚生労働省 : 平成 28 年度国民生活基礎調査の概況. http:// www.mhlw. go.jp/toukei/saikin/hw/k-tyosa/k-tyosa16/index. html（閲覧日2019年2月25日）.

3) Nakamura K: A "super-aged" society and the "locomotive syndrome". J Orthop Sci, 2008, 13: 1-2.

4) 石橋英明 :【ロコモティブシンドローム】運動機能低下・介 護リスク評価運動機能低下に気付くためのチェック法「ロコ チェック」. Mod Physician, 2010, 30: 473-477.

5) 日本整形外科学会：ロコモ度を判定する「臨床判断值」を 発表. https: //www.joa.or. jp/media/comment/pdf/20150515 locomo_clinical_judgment.pdf（閲覧日2019年2月 25 日）.

6) ロコモチャレンジ推進協議会 : https://locomo-joa.jp/check/ test/two-step.html（閲覽日2019年2月25日）.

7) 松本浩実, 萩野 浩：若年者と比較した高齢者の下肢運動 時筋電図分析。運動療法と物理療法, 2010, 21: 336-342.

8) Shumway-Cook A, Wollacott MH : モーターコントロール 運 動制御の理論から臨床実践へ, 原著第4版. 田中 繁·他(監 訳), 医歯薬出版, 東京, 2016, pp164-191.

9) Holden M, Ventura J, Lackner JR: Stabilization of posture by precision contact of the index finger. J Vestib Res, 1994, 4:
285-301.

10) Kouzaki M, Masani K: Reduced postural sway during quiet standing by light touch is due to finger tactile feedback but not mechanical support. Exp Brain Res, 2008, 188: 153-158.

11) Jeka JJ, Lackner JR: Fingertip contact influences human postural control. Exp Brain Res, 1994, 100: 495-502.

12) Jeka JJ, Lackner JR: The role of haptic cues from rough and slippery surfaces in human postural control. Exp Brain Res, 1995, 103: 267-276.

13) Baccini M, Rinaldi LA, Federighi G, et al.: Effectiveness of fingertip light contact in reducing postural sway in older people. Age Ageing, 2007, 36: 30-35.

14) Watanabe $S$, Ishida $H$, Kobara $K$, et al.: Influence of active fingertip contact with a stable surface on postural sway and electromyographic activities of the lower extremity muscles immediately after turning. Kawasaki J Med Welf, 2013, 19: $1-6$.

15 Watanabe S, Kobara K, Ishida H: Influence of fingertip contact with a wall on postural sway and electromyographyic activity of the soleus muscle. Electromyogr Clin Neurophysiol, 2010, 50: 229-233.

16) Lackner JR, Rabin E, DiZio P: Stabilization of posture by precision touch of the index finger with rigid and flexible filaments. Exp Brain Res, 2001, 139: 454-464.

17) Iwamoto Y, Takahashi M, Shinkoda K: Muscle co-contraction in elderly people change due to postural stability during single-leg standing. J Physiol Anthropol, 2017, 36: 43.

18) Uchida $Y$, Demura S: Body sway and muscle activity during one-leg stance with help using a hand. J Mot Behav, 2015, 47: 89-94.

19) 北林 保, 出村慎一, 野田政弘・他：静的立位保持に抢け る足圧中心動摇変数相互の関係の検討一領域別および性差 の観点から一. Equilib Res, 2003, 62: 34-42.

20) 太田 康, 矢部多加夫：体平衡検査. Med Technol, 2005, 33: 805-812.

21) Jeka JJ: Light touch contact as a balance aid. Phys Ther, 1997, 77: 476-487.

22) Lackner JR, DiZio P, Jeka J, et al.: Precision contact of the fingertip reduces postural sway of individuals with bilateral vestibular loss. Exp Brain Res, 1999, 126: 459-466.

23) 神崎素樹, 政二 慶: 指先触覚による求心性情報が高齢者 の立位バランス能力向上に及ぼす影響. 健康医科学研究助 成論文集，2010, 25: 52-62. 